\section{Open 2 ACcess}

DOI: $10.25040 /$ ntsh2020.01.12

For correspondence:

69 Pekarska str., Lviv, Ukraine, 79010

Е-пошта: uljaska.p@gmail.com

Received: Feb, 17, 2020

Accepted: Mar, 17, 2020

Published online: Apr, 15, 2020

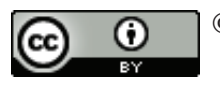

C) Uliana Pidvalna, Dmytro Beshley, Lesya Mateshuk-Vatseba, Vitaliy Averchuk, Liubomyr Kulyk, 2020

ORCID IDs

Uliana Pidvalna

https://orcid.org/0000-0001-7360-8111

Dmytro Beshley

https://orcid.org/0000-0002-4194-517X

Lesya Mateshuk-Vatseba

https://orcid.org/0000-0002-3466-5276

Vitaliy Averchuk

https://orcid.org/0000-0002-7333-6643

Liubomyr Kulyk

https://orcid.org/0000-0002-0394-0677

Disclosures. The authors declared no conflict of interest.

Author Contributions:

Concept - L.M-V., V.A., L.K., D.B.;

Design - L.M-V., U.P.;

Data Collectionand/or Processing -

V.A., L.K., D.B., U.P.

Literature Search - U.P., D.B.;

Writing Manuscript - U.P., D.B.

Critical Review - L.M-V., V.A., L.K., D.B.

Funding. The authors declared that this study had received no financial support.

UDC 616.132-007.64-089-06:616-018.2056.7]-091

\title{
Anatomy of aortic dissection in the patient with Marfan syndrome who underwent surgery: a case report
}

Uliana Pidvalna ${ }^{1}$, Dmytro Beshley 2, ${ }^{3}$, Lesya Mateshuk-Vatseba ${ }^{1}$ Vitaliy Averchuk ${ }^{3}$, Liubomyr Kulyk ${ }^{1,3}$

${ }^{1}$ Danylo Halytsky Lviv National Medical University, Lviv, Ukraine

2 Ukrainian-Polish Heart Center "Lviv", Lviv, Ukraine

${ }^{3}$ Lviv Regional Clinical Hospital, Lviv, Ukraine

Introduction. Aortic dissection is the most common acute aortic pathology. Acute ascending aortic dissection is a life-threatening condition and a surgical emergency which requires prompt visualization of the aortic anatomy.

Presentation of the case. Concurrent aortic dissection and Marfan syndrome (MFS) followed by the aneurysm of the aorta which required supracoronary aortic replacement (2012), Bentall procedure (2014) and urgent open thoracic descending aorta replacement (2017) are described in the case report.

Discussion. Patients with the aortic dissection may have certain underlying conditions, such as MFS, which can predispose to dissection. The aortic pathology is registered in almost 65$100 \%$ of the patients with MFS. The prevalence of Type A aortic dissection among the patients with MFS at the age of 60 is approximately $50 \%$. The most common pattern of repair is the proximal ascending aortic repair followed by the descending thoracic aneurysm surgery. The open surgery technique, as well as the aortic dissection or aneurysm repairs, may be safely used in the patients with MFS.

Conclusion. Anatomical features of the aorta in the patients with MFS are vitally important when carrying out the analysis of the computed tomography images; in particular, the schedule of the computed tomography follow-up for the patients with MFS should be customized to each case.

Keywords: Aortic aneurysm, dissection, computed tomography, aortic repair, type A dissection.

Cite this article as: Pidvalna U, Beshley D, Mateshuk-Vatseba L, Averchuk V, Kulyk L. Anatomy of aortic dissection in the patient with Marfan syndrome who underwent surgery: A case report. Proc Shevchenko Sci Soc Med Sci 2020;59(1):116-124. https://doi.org/10.25040/ntsh2020.01.12 


\section{УДК 616.132-007.64-089-06:616-018.2- 056.7]-091}

\section{Анатомія розшарування аорти в оперованої пацієнтки зі синдромом Марфана: опис клінічного випадку}

Уляна Підвальна ${ }^{1}$, Дмитро Бешлей ${ }^{2,3}$, Леся Матешук-Вацеба ${ }^{1}$, Віталій Аверчук ${ }^{3}$, Любомир Кулик ${ }^{1,3}$

1 Львівський національний медичний університет імені Данила Галицького, Львів, Україна

2 Україно-Польський центр серця "Львів", Львів, Україна

${ }^{3}$ КНП ЛОР "Львівська обласна клінічна лікарня", Львів, Україна

Вступ. Розшарування аорти є найбільш частою невідкладною патологією аорти. Гостре розшарування аорти типу A (Stanford) $є$ життєво-загрозливим станом та вимагає ургентного хірургічного втручання та детальної візуалізації анатомії аорти.

Опис клінічного випадку. Розшарування аорти у пацієнтки зі синдромом Марфана (СМ), що супроводжувалося аневризмою висхідної аорти, з приводу чого виконано супракоронарне протезування аорти (2012); аневризми кореня аорти, - як наслідок, операція Бентала (2014); ургентне протезування низхідної грудної аорти з приводу розриву аневризми несправжнього каналу даного сегменту аорти (2017).

Дискусія. У пацієнтів зі захворюванням сполучної тканини у шість разів частіше зустрічається розшарування аорти. Зокрема у пацієнтів зі синдромом Марфана патологія аорти діагностується у 65-100\% випадків. Частота розшарування аорти типу A (Stanford) серед пацієнтів зі СМ становить близько 50\%. Найбільш часті хірургічні втручання: супракоронарне протезування висхідного відділу аорти (методикою «повного кореня»), ремоделювання або реімплантація кореня аорти. Протезування дуги та низхідної грудної аорти - поодинокі випадки. Відкрита хірургія може безпечно застосовуватися у пацієнтів зі СМ як при розшаруванні, так і при справжніх аневризмах аорти.

Висновки. Анатомічні особливості аорти у пацієнтів зі СМ $€$ визначальними при аналізі зображень комп'ютерної томографії для планування стратегії хірургічного втручання. 3 метою прогнозування ускладнень та динаміки розвитку патології аорти у пацієнтів зі СМ після первинних оперативних втручань рекомендовано планові періодичні контрольні обстеження комп'ютерної томографії.

Ключові слова: аневризма аорти, розшарування аорти типу А, комп'ютерна томографія, протезування аорти. 


\section{Introduction/Background}

According to the World Health Organization, more people die annually from cardiovascular diseases (CVDs) than from any other cause. Over the last decades, CVDs have been the number one cause of death globally. Approximately 17.9 million people died from CVDs in 2016, which represents $31 \%$ of all global deaths (1). Apart from coronary heart disease and cerebrovascular diseases, which cause heart attacks and strokes, many people suffer from aortic pathology.

Aortic diseases contribute to a wide spectrum of arterial diseases, namely aortic aneurysms $(A A)$, acute aortic syndromes (AAS) including aortic dissection (AD), intramural haematoma $(\mathrm{IMH})$, penetrating atherosclerotic ulcer (PAU) and traumatic aortic injury (TAI), pseudoaneurysm, aortic rupture, atherosclerotic and inflammatory affections; genetic diseases and congenital abnormalities (2).

Aortic dissection is defined by the initial tear of the tunica intima with an entry of the luminal blood into the wall that results in the formation of the false lumen partitioned from the true lumen by the intimal flap (3). The incidence of acute aortic syndromes in the general population ranges from 4 to 6 cases per 100000 inhabitants a year but increases up to 30 or more in the people older than 65 years of age (4). In around $80 \%$ of cases, AD symptoms include an acute onset of chest pain that radiates to the back prompting the patient to seek medical care (5). Without the treatment, the lethality rate is $1-2 \%$ per hour after the sudden onset of the symptoms; the expected 90 -day mortality rate ranges from $70 \%$ to $90 \%$ if the surgical therapy is not performed (6). Undoubtedly, timely diagnosis is crucial to allow prompt surgical management (7). According to the International Registry of Acute Aortic Dissection (IRAD), the postoperative mortality rate has not gone down. Despite permanent improvements in the imaging techniques, medical management, the early mortality rate in the patients with Type A acute $A D$ repair ranging from $17 \%$ to $26 \%$ (8).

Undoubtedly, timely diagnosis is crucial to allow prompt surgical management (7). According to the International Registry of Acute Aortic Dissection (IRAD), the postoperative mortality rate has not gone down. Despite permanent improvements in the imaging techniques, medical management, the early mortality rate in the patients with Type A acute $A D$ repair ranging from $17 \%$ to $26 \%$ (8).

In order to study the aortic disease, it is essential to understand the anatomy of the aorta. To be able to manage the disease, it is of the utmost importance to choose the right diagnostic methods to assess the problem and find the best approach to deal with it.

Key Clinical Message. Marfan Syndrome may cause aortic pathology. We experienced a case of an acute Type A dissection in a patient with a Marfan Syndrome. Contrast-enhanced computed tomography revealed an acute Type A dissection. The patient successfully underwent supracoronary aortic replacement. Hereditary connective tissue disorder provoked further aortic root aneurysm (treated by Bentall procedure) and dissection of the descending thoracic aorta (urgent open thoracic descending aorta replacement).

\section{Anatomy of aorta}

The gross anatomy of the aorta is divided into segments: 1 - the aortic root; 2 - the sinotubular junction (STJ); 3 - the ascending aorta; 4 - the aortic arch; 5 - the descending (thoracic) aorta and 6 - the abdominal aorta. Depending on the segment, the approach to diagnostic procedures has to be different. Computed tomography (CT) reconstruction of a normal aorta has a different segmentation, which is as follows: segment I - the aortic root; segment II - the tubular ascending aorta (subdivided into IIa (STJ to the pulmonary artery level) and IIb (from the pulmonary artery level to the brachiocephalic artery)); segment III - the aortic arch; segment IV - the descending thoracic aorta (subdivided into IVa (from the left subclavian artery to the level of the pulmonary artery) and IVb (from the level of the pulmonary artery to the diaphragm)); and segment V - the abdominal aorta (subdivided into Va (the upper abdominal aorta from the diaphragm to the renal arteries) and $\mathrm{Vb}$ (from the renal arteries to the iliac bifurcation)) (9) (Fig. 1).

Visualization of the aortic arch and its branches helps to identify the extent of the dissection of the aorta as well as assess whether the brachiocephalic artery, the left common carotid artery and the left subclavian artery are affected by the pathological process. The information concerning the severity of the ca- 


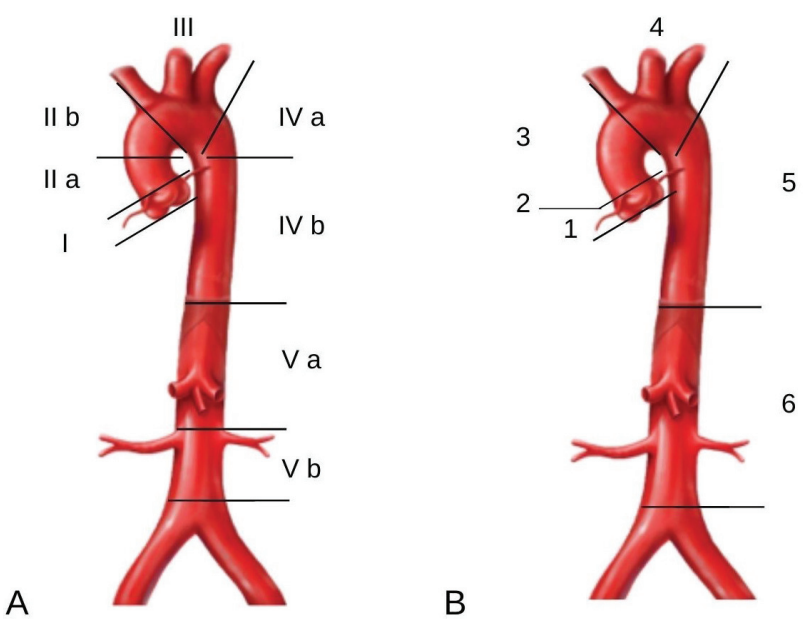

Figure 1. Schematic visualization of the aorta. A, Segmental division of the aorta (describing CT scan). B, Segmental division of the aorta (anatomical). Drawn by Uliana Pidvalna

rotid artery stenosis, condition of the subclavian artery (as a possible site of cannulation) is helpful for the diagnosis, monitoring and decision-making during the aortic surgery (10).

\section{Case presentation}

Stage 1. A 35-year-old woman with Marfan syndrome (MFS) was brought to the cardiac surgery department of the Lviv Regional Clinical Hospital being diagnosed with Acute Aortic Syndrome (2012). Clinical diagnosis of MFS was made based on the Ghent nosology. According to it, the clinical picture: ectopia lentis (consulted by an ophthalmologist) and family history (MFS was diagnosed in patient's father; diagnosed by a genetic counsellor) are sufficient for a diagnosis of MFS.
Diagnostic algorithm for the acute thoracic pain included contrast-enhanced computed tomography (CECT), which showed Type A AD with the intimal tear in the ascending aorta, patency true and false lumens (Fig. 2). The dissection involved the entire aorta till the aorta bifurcation. Thoracic aortic dimensions according to CECT: aortic root: $33 \mathrm{~mm}$; sinus of Valsalva: $39 \mathrm{~mm}$; STJ: $40 \mathrm{~mm}$; tricuspid aortic valve (TAV); aortic regurgitation: trivial. The celiac trunk, as well as the mesenteric and renal arteries, originated from the true lumen of the aorta. Hemodynamically unstable: tamponade, in cardiogenic shock, without signs of visceral ischemia. The patient underwent emergency surgery with a supra-coronary replacement of the ascending aorta (SCAR) with the resuspension of the aortic valve (Deep Hypothermic Circulatory Arrest with Selective antegrade cerebral perfusion (DHCA + SACP)).

The process of the recovery was uneventful, and the patient was discharged in good condition nine days after the surgery had been carried out. Thoracic and abdominal CECT routinely performed for the post-operatory control showed uncomplicated ascending aortic graft, residual dissection from distal anastomosis, which extended to the bifurcation. The patient was informed about the regular CT follow-up.

Stage 2. In 2 years (2014) the same woman (37-year-old) with MFS was brought to the cardiac surgery department of the Lviv Regional Clinical Hospital with the following symptoms: fatigue and weakness, shortness of breath, swollen ankles and feet, heart murmur, etc.

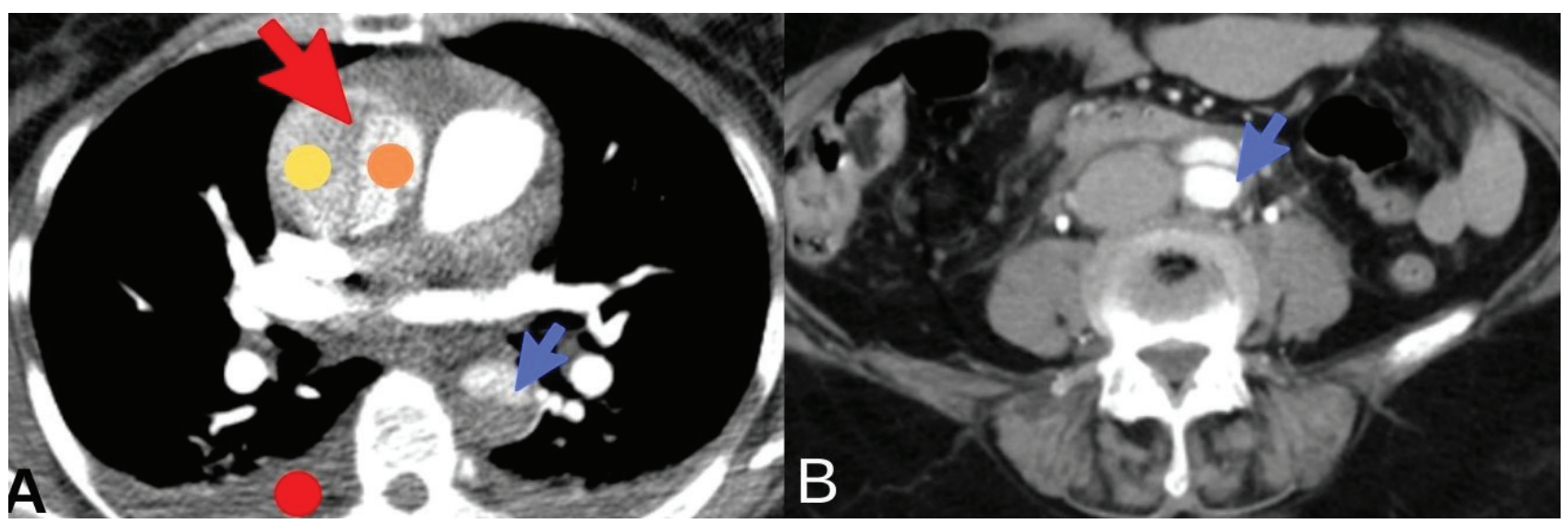

Figure 2. A, Axial CT images show the initial intimal tear in the ascending aorta (red arrow) and reentry in the descending thoracic aorta (blue arrow) as well as pleural fluid (red circles). The intimal flap, true (orange circle) and false lumen (yellow circle). B, The dissection flap extending into the aorta bifurcation (blue arrow). CECT images 

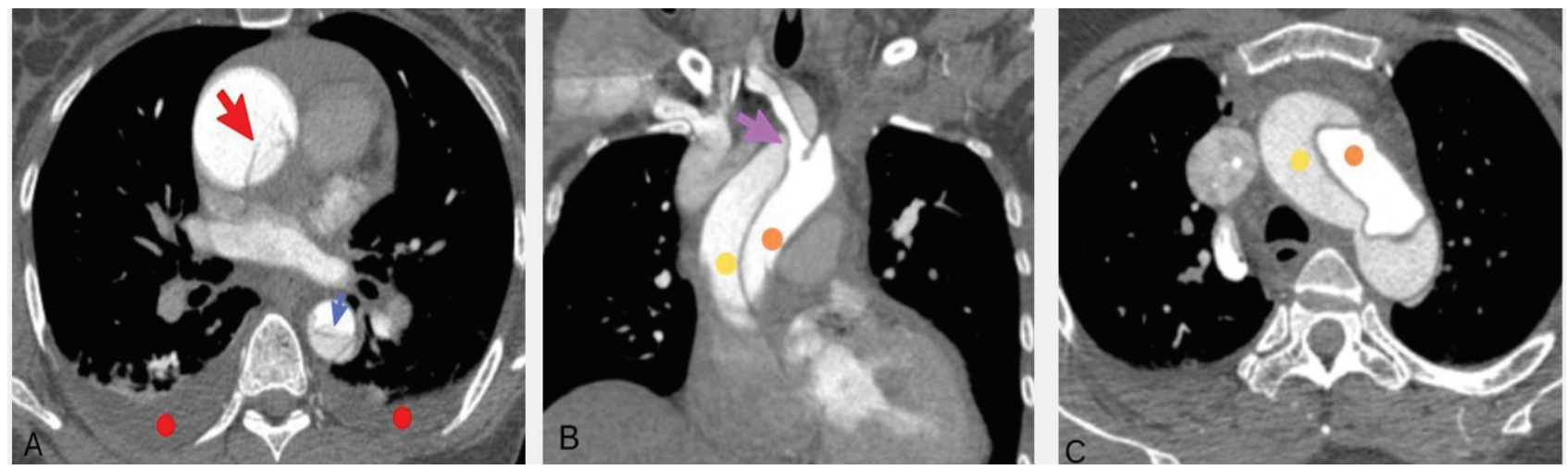

Figure 3. A, Axial CT image shows the initial intimal tear in the ascending aorta (red arrow) and reentry in the descending thoracic aorta (blue arrow) as well as pleural fluid (red circles). B, The coronal reformatted image from the same patient shows the dissection flap extending into the innominate artery (purple arrow). B, C, The intimal flap, true (orange circle) and false lumen (yellow circle). CECT images

Clinical data: aortic root aneurysm; diameter of sinuses of Valsalva $68 \times 85 \mathrm{~mm}$ (Fig. 3); severe aortic valve regurgitation; NYHA III. Diagnosis - Chronic Type A AD with MFS, condition after SCAR. Surgical Decision: REDO: Bentall procedure (graft replacement of the aortic valve, the aortic root and the ascending aorta with re-implantation of the coronary arteries into the graft). The patient was released from the hospital without any major complications.

Stage 3. In 3 years (2017) after developing sudden severe chest pain, shortness of breath and diaphoresis the same woman (40-year- old) with MFS was brought to the emergency department. A rupture of the dissected aorta was suspected, and the chest and abdomen CECT was obtained. The patient was diagnosed with the rupture of the false lumen of the descending thoracic aorta; paraesophageal hematoma; hemomediastinum (superior mediastinum); massive right hemothorax was established by CT imaging (Fig. 4, Fig. 5). The patient underwent surgery immediately. Surgical Decision: REDO: urgent open thoracic descending aorta replacement. During operation: chronic DAA of the thoracic aorta with diameter $80 \mathrm{~mm}$ in IVa segment and roughly
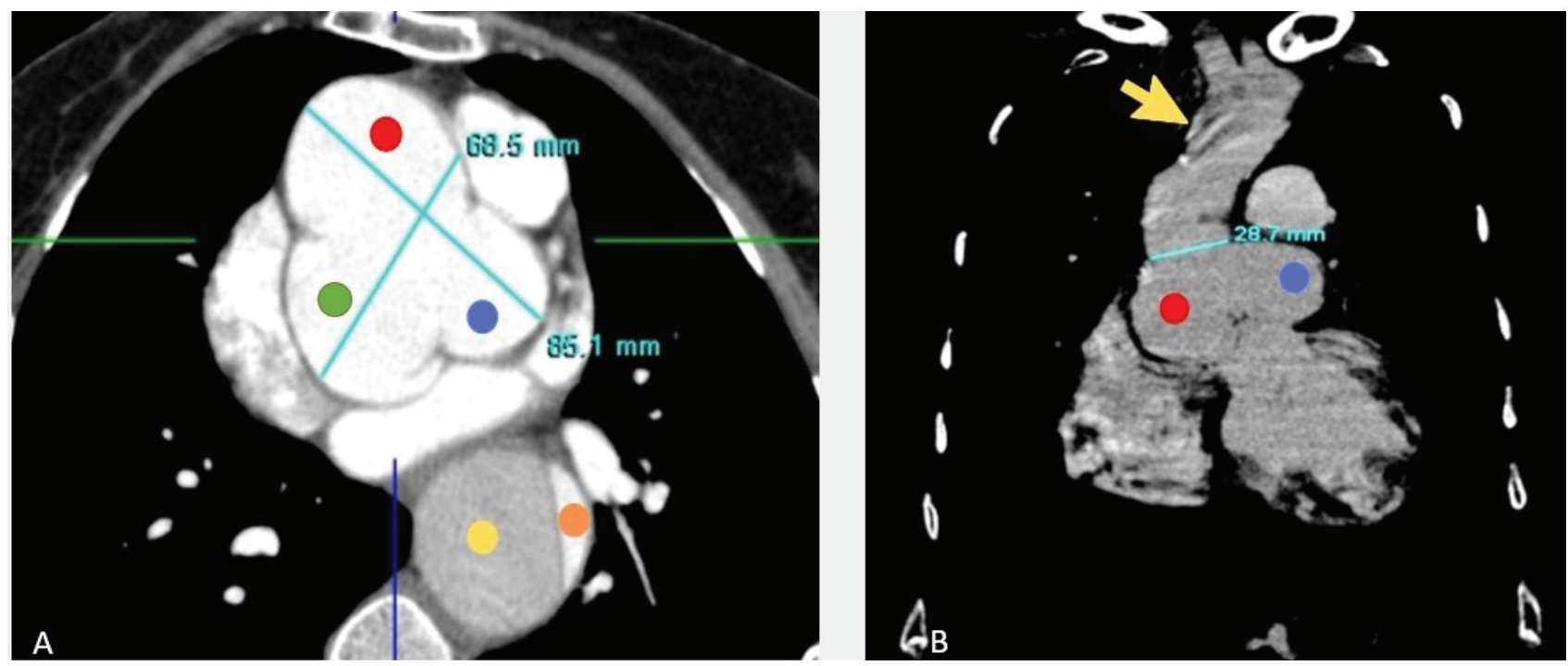

Figure 4. A, B, The patient with Marfan syndrome and chronic Type A AAD. CT-scans after SCAR and resuspension of AV (DHCA + SACP). Sinus Valsalva aneurysm: right coronary sinus (red circle), left coronary sinus (blue circle), noncoronary sinus (green circle). A, The intimal flap, true (orange circle) and false lumen (yellow circle). CECT image. B, The coronal reformatted image. The Dacron aortic prosthesis 28 $\mathrm{mm}$ in diameter (yellow arrow) 

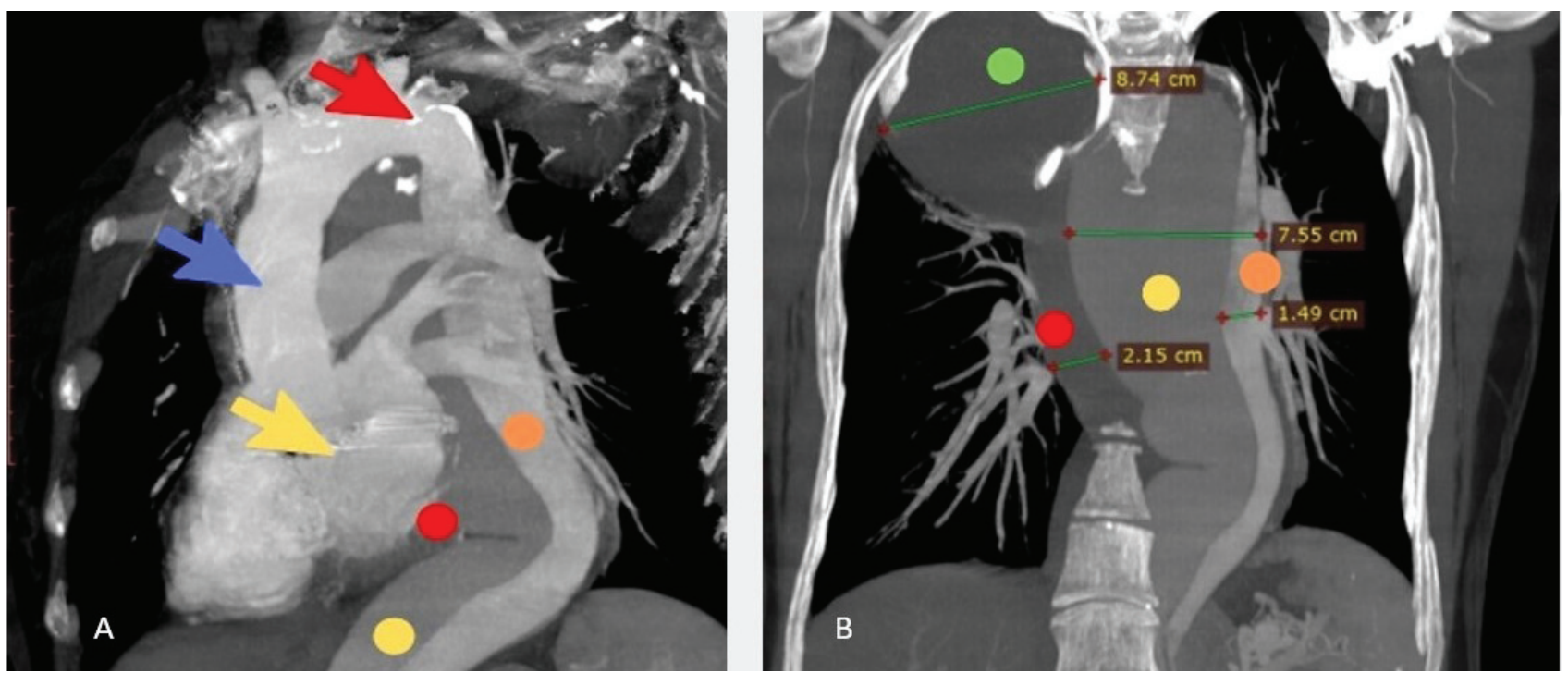

Figure 5. A, B, The patient with MFS and chronic Type A AD. CT-scans after REDO: Bentall procedure. Aortic dissection, true (orange circle) and false lumen (yellow circle) with hematoma in posterior mediastinum (red circle) and upper posterior mediastinum (green circle). A, The mechanical aortic valve prosthesis 23 mm (yellow arrow), the Dacron aortic prosthesis $28 \mathrm{~mm}$ in diameter (blue arrow), the calcified proximal part of the descending aorta (red arrow)

$40 \mathrm{~mm}$ in Va segment. Proximal anastomosis: the proximal part of the descending aorta and the Dacron aortic prosthesis $28 \mathrm{~mm}$; distal anastomosis - the full root technique: the distal thoracic aorta (Th7-Th8 level) and the Dacron aortic prosthesis $28 \mathrm{~mm}$.

The patient showed postoperative pelvic ischemia (caused by spinal ischemia) and lower extremity disorders, which were managed by continuous conservative treatment. Other- wise, the patient recovered well and was discharged after the operation with the follow-up at the outpatient clinic (Fig. 6).

Histological examinations of the operating material were performed after each stage of surgical procedure. Morphological changes of media were characterized by severe restructuring and deep irreversible changes in all components. The typical pathomorphological signs of MFS were detected: cystic medial necrosis, degra-
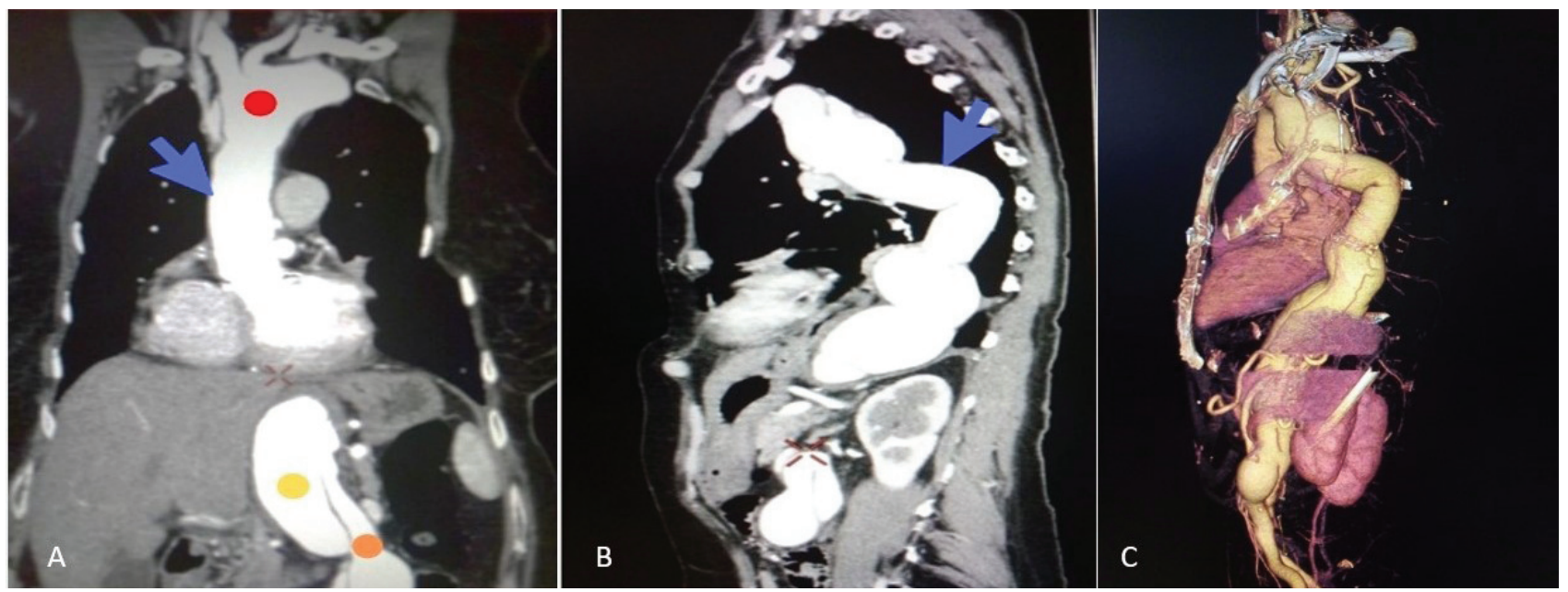

Figure 6. A, B, The patient with MFS and chronic Type A AD. CT-scans after urgent open thoracic descending aorta replacement. The Dacron aortic prosthesis $28 \mathrm{~mm}$ in diameter (blue arrow). Non-touch patient's aortic arch (red circle), both patency true and false lumens (orange / yellow circles). CECT image. C, 3-D reconstruction of the aorta after three stages 
dation and destruction of elastic layer, degenerative changes in smooth muscle cells, focal accumulation of mucoid substances.

\section{Discussion}

Aortic dissection is the most common acute aortic pathology (11). The last report of the Global Burden Disease 2010 project demonstrated that the overall global death rate from $A A$ and $A D$ increased from 2.49 per 100000 to 2.78 per 100000 inhabitants between 1990 and 2010, with higher rates for men (12). Acute ascending aortic dissection is a life-threatening condition and a surgical emergency that requires prompt diagnosis and treatment (13); if left untreated, the lethality rate is $1-2 \%$ per hour after the sudden onset of the symptoms. Without surgical therapy, the expected 90-day mortality rate ranges from $70 \%$ to $90 \%$ (6). $60 \%$ of all the thoracic aortic aneurysms involve the aortic root, the ascending aorta, or both; there is a cumulative yearly risk of rupture or dissection of up to $6.9 \%$ per year with the maximal diameter being bigger than 60 $\mathrm{mm}$ (7). According to the IRAD, Type A dissections, if left untreated, kill $33 \%$ of the patients within the first 24 hours, $50 \%$ within 48 hours and $75 \%$ within two weeks.

The symptoms of AAD are widely described, and despite the recent advances in diagnostic methods, misdiagnosis occurs in $25-50 \%$ of patients during the initial evaluation with the symptoms mimicking those of the acute myocardial infarction and other cardiovascular disorders (14). As a result, the time is lost, which, in turn, provokes hemodynamic instability, hemorrhagic pleural and pericardial effusions. The factors mentioned above increase hemorrhagic postoperative complications and reinforce the trend toward increased mortality (14). It can be the reason for a high postoperative mortality rate as reported by the IRAD.

Acute $A D$ can develop into a chronic phase 90 days after the onset of the symptoms (2). Some authors describe chronic dissection as being safer and having a better prognosis as compared to the acute one. Chronic AD can either be uncomplicated, with a stable disease course or complicated by progressive aneurysmal degeneration, chronic visceral or limb malperfusion as well as persisting or recurrent pain or even rupture (5).
In the presented case, aneurysmal degeneration was the complication of chronic AD, which resulted in the patient being taken to the hospital for the second time with REDO (second stage). Uneventful recovery and the discharge from hospital in good condition could have been the final stage, but the additional problem arose, i.e. the genetic disorders. Marfan, Ehlers-Danlos, Loeys-Dietz and Turner syndrome, or bicuspid aortic valve, are conditions associated with an increased risk for aortic dissection (15).

The woman in question had a family history of MFS, which resulted in the development of the disorders in connective tissue (2). In this case, two criteria: ectopia lentis (dislocation of the natural crystalline lens) and family history are sufficient for a diagnosis of MFS according to the Ghent Nosology. Without family history, the ectopia lentis and aortic root aneurysm are also enough to set the diagnosis of MFS. Very often, the history of hereditary connective tissue disorders in patients is unknown, which require further investigation.

Hereditary connective tissue disorders generally have common pathomechanism. It includes abnormal extracellular matrix assembly and homeostasis, increasing TGF- $\beta$ signalling, and disruption of the vascular smooth muscle cell contractile apparatus (16). Despite the similar pathomechanism, each syndrome has specific clinical manifestation, gene codding and histological peculiarities of the vascular wall. Keep in mind that appropriate genetic testing should be performed to set the right diagnosis (TDFBR1/2, TGFB2, TGFB3, SMAD3, COL3A1, collagen biochemistry, etc.). However, up to date, several risk genes are still unknown (16), some testing is not broadly available, and a given mutation may be either silent (17).

From $6 \%$ to $8 \%$ of the patients with Type $A$ acute $A D$ has MFS, i.e. a hereditary disorder with the defect of the fibrillin 1 (FBN 1) gene. The aortic pathology is registered in almost $65-100 \%$ of the patients with MFS. The prevalence of Type A dissection among the patients with MFS at the age of 60 is approximately $50 \%$. Owing to the CT follow-up, the patient was diagnosed with the rupture of the false lumen of the descending thoracic aorta, paraesophageal hematoma, hemomediastinum (superior mediastinum); massive right 
hemothorax was established by $\mathrm{CT}$ imaging. The given conditions required urgent surgical decision to be made in order to save the patient's life. After analyzing the anatomy of the aorta, the surgical decision was REDO: urgent open thoracic descending aorta replacement.

There are several diagnostic tools to assess the aorta that are mainly based on imaging techniques. CECT plays the central role in the diagnosis, risk stratification and management of the aortic diseases (according to the European Society of Cardiology Guidelines (2014) (2).

There is a comprehensive list of questions concerning the anatomy of aortic dissection which must be answered. The key to successful treatment is a visualization of the aortic pathology. Firstly, information must be collected. It has to fulfil preoperative requirements for the surgical intervention: initial intimal tear; aortic diameter; entry and reentry sites; patency of the false lumen; hemopericardium / tamponade?; aortic branch and coronary ostia involvement; aortic valve competency; blood extravasation in the surrounding spaces.

Visualization of the aortic arch and its branches helps to identify the extent of the dissection of the aorta as well as assess whether the brachiocephalic artery, the left common carotid artery and the left subclavian artery are affected by the pathological process. The information regarding the severity of the carotid artery stenosis, condition of the subclavian artery (as a possible site of cannulation) is helpful for the diagnosis, monitoring and decision-making during the aortic surgery (10), especially in cannulation site.

Besides modern visualization techniques, MFS has a morphological basis, and histological examination could reveal the depth and severi- ty of connective tissue disorders. Pathological changes in elastic fiber structure and destabilizing the interaction between vascular cells and matrix scaffold are described while fibrillin-1 mutation. Recent studies describe the importance of biomarkers of inflammation, and/ or thrombus formation and related cytokines for acute aortic pathology, especially for AAD. There is a list of potential biomarkers of AAS: smooth muscle myosin heavy chain (SM-MHC), BB isotype of creatine kinase (CK-BB), calponin, soluble elastin fragments (sELAF), matrix metalloproteinases (MMPs), circulating transforming growth factor (TGF) B, D-dimer, granulocyte-macrophage colony-stimulating factor (GM-CSF) Interleukin-6 (IL-6) (18).

Study limitations: absence of genetic testing and specific blood test markers (SM-MHC; CK-BB; calponin; sELAF, MMPs, TGF B, GM-CSF, IL-6.

In conclusion, anatomical features of the aorta in the patient with MFS as well as stages of the development of the aortic aneurysm till the dissection of the false lumen are described in the case report. The analysis shows that patients after the first stage surgery of acute $A D$ should be examined with $C T$ scan at least once a year. In case the scan verifies that the standard dimensions of the aorta are exceeded, or the true or false lumens are dilated, the patients must undergo surgery. The most common pattern of repair is the proximal ascending aortic repair which is followed by the descending thoracic aneurysm surgery.

The case-report provides the description of the concurrent aortic dissection and MFS followed by the aneurysm of the aorta, which required SCAR (2012), Bentall procedure (2014) and urgent open thoracic descending aorta replacement (2017).

\section{Footnotes}

The article is associated with the abstract presented by the authors at the European Congress of Radiology (Vienna, 11-15 March 2020).

Ethics Committee Approval: Bioethics Commission of Danylo Halytsky Lviv National Medical University, protocol № 423 April, 2018.

Informed Consent: Written informed consent was obtained from the patient who participated in the study. 


\section{References}

1. World Health Organization. Cardiovascular diseases. 17 May 2017. Available from: https://www.who.int/ news-room/fact-sheets/detail/cardiovascular-diseases-(cvds). Accessed on 15 January 2020.

2. Task A, Erbel R, Germany C, Aboyans V, France C, France CB, et al. ESC Guidelines on the diagnosis and treatment of aortic diseases of the European Society of Cardiology (ESC). Eur Heart J. 2014;(35):2873926.

3. Loewe C. Acute Aortic Syndromes. In: Multislice CT. Springer International Publishing AG; 2019:825-53.

4. Gawinecka J, Schönrath F, von Eckardstein A. Acute aortic dissection: pathogenesis, risk factors and diagnosis. Swiss Med Wkly. 2017; 147(August):w14489.

5. Yusuf Beebeejaun M, Malec A, Gupta R, Alkhawam H. Conservative management of chronic aortic dissection with underlying aortic aneurysm. Heart Int. 2013 Mar 15;8(1):e4.

6. Gionis MN, Kaimasidis G, Tavlas E et al. Medical management of acute Type A aortic dissection in association with early open repair of acute limb ischemia may prevent aortic surgery. Am J Case Rep. $2013 ; 14: 52-7$.

7. Freeman LA, Young PM, Foley TA, Williamson EE, Bruce CJ, Greason KL. CT and MRI assessment of the aortic root and ascending aorta. Am J Roentgenol. 2013;200(6):581-92.

8. Berretta P, Patel HJ, Gleason TG et al. IRAD experience on surgical Type A acute dissection patients: results and predictors of mortality. Ann Cardiothorac Surg. 2016;5(4):346-51.

9. Goldstein SA, Evangelista A, Abbara S, Arai A, Asch FM, Badano LP, et al. Multimodality imaging of diseases of the thoracic aorta in adults: From the American society of echocardiography and the European association of cardiovascular imaging. J Am Soc Echocardiogr. 2015;28(2):119-82.

10. Patil TA, Ambli SK. Transesophageal Echocardiography Evaluation of the Aortic Arch Branches. Ann Card Anaesth. 2018;21(4):53-6.

11. Hagan PG, Nienaber CA, Isselbacher EM, Bruckman D, Karavite DJ, Russman PL, et al. The International Registry of Acute Aortic Dissection (IRAD). 2000;283(7).

12. Wang S-W, Huang Y-B, Huang J-W, Chiu C-C, Lai W-T, Chen C-Y. Epidemiology, Clinical Features, and Prescribing Patterns of Aortic Aneurysm in Asian Population From 2005 to 2011. Medicine (Baltimore). 2015 Oct;94(41):e1716.

13. Elsayed RS, Cohen RG, Fleischman F, Bowdish ME. Acute Type A Aortic Dissection. Cardiol Clin. 2017;35:90033.

14. Kim HJ, Lee HK, Cho B. A case of acute aortic dissection presenting with chest pain relieved by sublingual nitroglycerin. Korean J Fam Med. 2013;34(6):429-33.

15. Silvestri V, Mazzesi G, Mele R. Postpartum aortic dissection. A case report and review of literature. Int J Surg Case Rep. 2019;56:101-6.

16. Renner S, Schüler H, Alawi M, Kolbe V, Rybczynski M, Woitschach R, et al. Next-generation sequencing of 32 genes associated with hereditary aortopathies and related disorders of connective tissue in a cohort of 199 patients. Genet Med. 2019;21(8):1832-41.

17. Goyal A, Keramati AR, Czarny MJ, Resar JR, Mani A. The Genetics of Aortopathies in Clinical Cardiology. Clin Med Insights Cardiol. 2017;11:1-11.

18. Suzuki T., Sawaki D. Biomarkers of Acute Aortic Syndrome. In: Stanger O., Pepper J., Svensson L. (eds). Surgical Management of Aortic Pathology. Springer, Vienna; 2019:233-41. 